\title{
The moderating impact of resilience on the relationship between workplace incivility and turnover intentions: a proposed study in Dubai retail SME's
}

\author{
Yasin Shahryari \\ University of Dubai \\ E-mail: $\underline{\text { s0000000068@ud.ac.ae }}$ \\ Kamarul Zaman Ahmad \\ Dubai Business School, University of Dubai \\ E-mail: kbinahmad@ud.ac.ae
}

\begin{abstract}
This is a theoretical paper that aims to explore the determinants of employee turnover intention among retail SMEs in Dubai in terms of incivility (customer, coworker, supervisor) and the mediating role of emotional exhaustion with the moderating effect of resilience.

The retail industry in Dubai will be one of the main beneficiaries of the study since it appears that they suffer high turnover intention and cost. Managements and owners of retail SMEs in Dubai would be able to get a better idea of the determinants of employee turnover intention and workplace incivility through the analysis and recommendations developed by the research.

Data would be gathered from participants (i.e. employees of retail SMEs in Dubai) who have direct contact with customers, coworkers and supervisors/ management. Viewed in this manner, data gathered would be analyzed in two stages, using descriptive statistics and structural equation modeling using computer software including, SPSS/STATA, AMOS/ Smart-PLS.

This paper would elaborate the literature on turnover intention and incivility Subsequently, the research will illustrate the mediating role emotional exhaustion and the moderation effect of resilience among retail SMEs employees in Dubai.
\end{abstract}

Keywords: Incivility, Turnover intentions, Resilience, SMEs

http://dx.doi.org/10.30585/icabml-cp.v1i1.24

2523-6547 - Copyright: (C) 2017 The Authors. This is an open access article distributed under the terms of the Creative Commons Attribution License, which permits unrestricted use, distribution, and reproduction in any medium, provided the original author and source are credited. 


\section{Introduction}

Emaratalyoum (2015), states that $15 \%$ of locals in the UAE, leave their job before the first year of work completion. The UAE market has been affected significantly due to employee turnover over years in terms of economical cost. These employees are multicultural, different religion and from different background and nationalities (Maceda, 2017). CEOs report that employee turnover is significantly on rise and one of the key reasons is the work life balance (Maceda, 2014).

The Research question in this study is, What is the significance of incivility in Dubai retail SMEs with regards to turnover intention? Does resilience play a significant role?

There is limited research done on turnover intention in the MENA region and only countable number of research (3) done in the UAE context (close to Dubai), with focus on Oil \& Gas and Hotel industry.

Literature review

i) Historical background:

Employee turnover is the number or percentage of employees leaving the organization. There are two main types of turnover; employees leaving the organization voluntarily and sometimes the organization have to discharge employees over a period of time (Saeed et al., 2014). Consequently, it is important to know that all kind of employee turnover incurs cost to the organization.

Previous studies on turnover intention indicate that job satisfaction has a high relationship for employees quitting job (Chen et al., 2012). Similarly, other studies conducted cross borders (across countries like China, Turkey, Jordan) state that variables such as organizational commitment, employee development, performance pay, perceived organizational support, demographic variables, etc. are related to turnover intention of employees within a specific organization over a period of time (Saeed et al., 2014; Medina, 2012; Samad, 2006; Chen et al., 2012; Peachey et al., 2014; O’Halloran, 2012; Poon, 2014).

Although there is limited literature/study on turnover intention in Dubai and the MENA region there are rich literature done in different context such as the Western world, China, Jordan, Turkey and other Asian countries.

Saeed et al. (2014) conclude that Turnover has significant cost to organizations and it is of great significance to identify the factors affecting turnover intention.

Looking at the current and past literature, it is observed that there are several factors that determine employee turnover intention in various studies conducted across different disciplines and context. Therefore the significance of the research question with regards to the determinants of employee turnover intention among retail SMEs in Dubai through focusing on different factors and building on the literature with the context of Dubai and retail SMEs in Dubai.

In the United Arab Emirates, the economy is suffering significantly from high employee turnover with majority being expatriates (Gulfnews, 2008). Harhara et al. (2015) state that the UAE has been suffering from high turnover and have considered the Oil and Gas industry in UAE as the context of the study towards identifying the factors

2523-6547 - Copyright: (C) 2017 The Authors. This is an open access article distributed under the terms of the Creative Commons Attribution License, which permits unrestricted use, distribution, and reproduction in any medium, provided the original author and source are credited. 
affecting turnover intention. Further, the study propose that environmental factors such as work life balance would have an impact on employees working in remote areas and organizational commitment will play a mediating role between environmental factors and turnover intention.

This study aims to build on the existing literature with regards to employee turnover intention in the context of SMEs through focusing on the under looked area of retail SMEs operating in Dubai, that is one the fastest growing countries and a global business hub. Further, despite the existing literature on SMEs and turnover intentions, the literature on SMEs will be improved by looking at turnover intention from work incivility perspective among SMEs.

ii) All relevant theories to research question:

Many theories have been identified with regards to turnover intention within the literature, such as; attitudebehavior theory, Maslow's hierarchy of needs, Hezberg, motivation theories (Samad \& Mara, 2006), social exchange theory, human capital theory (Rahman \& Nas, 2013), relationship marketing theory (Wang, 2014), expectancy theory (Zimmerman \& Darnold, 2009), etc. for the purpose of this study, three theories of Maslow, human capital and social exchange theory have selected as relevant theories due to the nature of the study, that is, turnover intention. Turnover is referred as an individual's estimated probability that they will stay an employing organization (Cotton \& Tuttle, 1986). Meanwhile Tett \& Meyer (1993) defined turnover intentions as conscious willfulness to seek for other alternatives in other organization.

iii) Current empirical literature relevant question or hypothesis:

Customer incivility

Andersson \& Pearson (1999) define workplace incivility as "low-intensity deviant behavior with ambiguous intent to harm the target, in violation of workplace norms for mutual respect. Uncivil behaviors are characteristically rude and discourteous displaying a lack of regard for others " (p. 457).

Aggression in workplace environment is generally divided into two main centers of intra-organization and extraorganizational factors. Intra-organization factors such as, interpersonal conflict, workplace bullying and abusive supervision (Tepper, 2000). Extra-organizational factors consider customer and a stakeholder view of aggression (Li \& Zhou, 2013).

According to poddar and Madupalli (2012): customer's aggressive behaviors lead to significant negative affect on customer service emotional wellbeing.

Customer incivility is one of the most significant determinants of emotional exhaustion among service employees (Dorman and Zapf, 2004: Hur et al. 2016). Customer incivility may not act as a treat to the firm or individual in single occurrence, but if has a daily or routine form, it will impact the individual's emotional exhaustion (Kern and Grandey, 2009). However, research proves that service employees report significant amount of workplace incivility from customers than coworkers and other sources of incivility (Grandey et al. 2007). Consequently, in order to fulfill the purpose of the research, the following hypotheses is considered,

H1a: customer incivility has a positive relationship with retail SMEs employees' emotional exhaustion in Dubai.

\section{Co-worker incivility and emotional exhaustion}

Similar to customer incivility, coworker incivility is when an employee is faced by rude and uncivil action by another employee (Hur et al., 2016). According to Porath and Pearson (2010) employees who have faced incivility

2523-6547 - Copyright: (C) 2017 The Authors. This is an open access article distributed under the terms of the Creative Commons Attribution License, which permits unrestricted use, distribution, and reproduction in any medium, provided the original author and source are credited. 
at work will not be able to concentrate and be productive at work, since they are afraid that incivility will take place. Viewed in this manner, coworker incivility will lead to job stress (Lim and Cortina, 2005) and reduce the level of work satisfaction for the employee faced by incivility from a colleague (Lim et al., 2008). Other negative results of coworker incivility that involve uncivil acts with the intent to harm other employees by not saying please or thank you (Pearson et al., 2001), include, reduced mental well-being (Lim and Cortina, 2005), increase emotional exhaustion (Laschinger et al., 2009).

Cho et al. (2016) study, looked at workplace incivility in terms of customer, supervisor and coworker incivility, the study indicated that workplace incivility will increase emotional exhaustion to a great deal and will reduce the staff performance in the restaurant industry. Another similar studies conducted in the Indian restaurant industry indicate that mistreatment at work and uncivilized behavior reduces job satisfaction and is a strong predictor of employee turnover intention (Sharma and Singh, 2016).

H1b: coworker incivility has a positive relationship with retail SMEs employees' emotional exhaustion in Dubai.

Supervisor incivility and emotional exhaustion

According to Hung and Yoon (2014) restaurant workers face high stress at work sue to mistreatment from coworkers and superiors which leads to increase emotional exhaustion. Study by Han et al. (2016) investigated customer incivility in restaurants in US and confirmed that organizational support and supervisory support moderate the relationship between customer incivility and turnover intention.

Earlier research by Tepper (2000) looked at incivility in terms of abusive supervisor, the study concluded that employees with abusive supervisors had lower satisfaction at work and were highly to quite their jobs.

H1c: supervisor incivility has a positive relationship with retail SMEs employees' emotional exhaustion in Dubai.

\section{Emotional exhaustion (mediating effect)}

Harhara et al. (2015) have looked at the oil and gas industry in terms of emotional, organizational and individual factors in relation to turnover intention. In conclusion, they have developed a framework for turnover intention based on different factors and this results may not be used implemented in other industries. We add to this literature and practice by looking at turnover intention in the context of retail SMEs in Dubai and studying turnover intention with regards to workplace incivility.

Hur et al. (2016) conducted research on workplace incivility (Coworker \& Customers) with relations to employee creativity and emotional exhaustion (mediator), in Korea hotels. Using sample from three hotels only. They concluded that incivility from coworkers and customers would reduce creativity and emotional exhaustion is a significant mediator. Consequently, we aim to build on this study, by adding supervisor incivility and testing the relationship with employee turnover intention by obtaining sample from various retail SMEs in Dubai.

2523-6547 - Copyright: (C) 2017 The Authors. This is an open access article distributed under the terms of the Creative Commons Attribution License, which permits unrestricted use, distribution, and reproduction in any medium, provided the original author and source are credited. 
H2: emotional exhaustion mediates the relationship between workplace incivility and employee turnover intention among retail SMEs in Dubai

\section{Resilience (moderating effect)}

Shabir et al. (2014) looked at resilience as part of psychological capital that acts as a moderator between work incivility and job stress as the outcome.

H3: Resilience moderates the relationship between workplace incivility and employee emotional exhaustion

Conceptual framework:

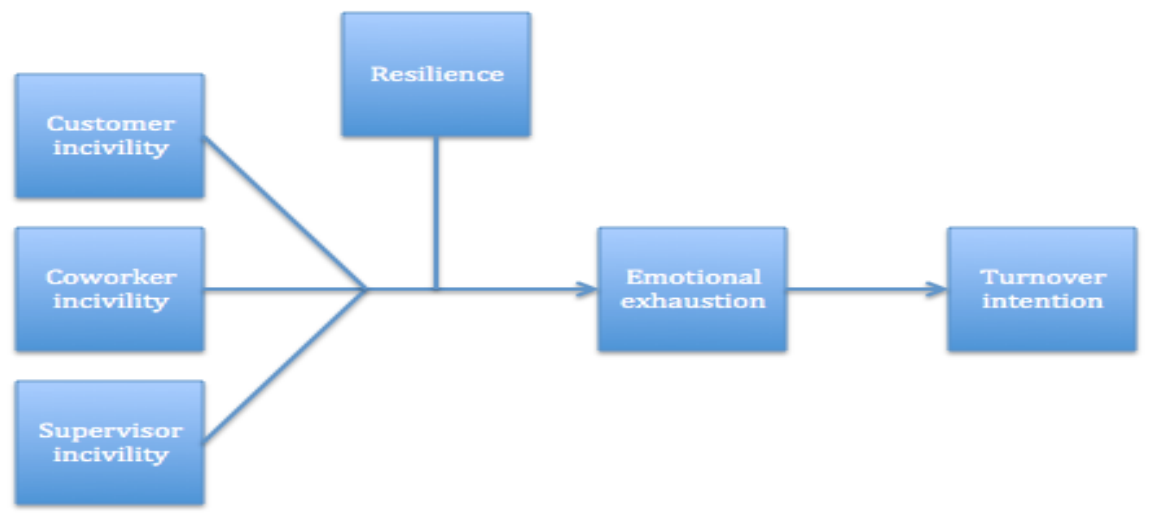

Theoretical \& Practical Contributions,

These articles have looked at incivility separately, but this research will combine the different aspects/ dimensions. Further, no of these articles and no other articles have looked at resilience that is the PE-fit with regards to incivility and employee turnover intention. When an empirical analysis of this study is completed, the findings will provide valuable insights to managers and employees on the importance of reducing and coping with such uncivilized behavior from the various sources.

Limitations

- The study is limited to employees in retail SMEs and it may not be generalize outside this population such as oil industry.

- Other variables (dimensions) may have been considered, but due to the scope (focus) of the research they have not been included

- Population (sample) non-supervisory employees, since they are considered as a factor for turnover in this study

- This study covers the retail SMEs operating in Dubai-UAE. However, other geographical areas may be considered for further research.

2523-6547 - Copyright: (C) 2017 The Authors. This is an open access article distributed under the terms of the Creative Commons Attribution License, which permits unrestricted use, distribution, and reproduction in any medium, provided the original author and source are credited. 
2523-6547 - Copyright: (C) 2017 The Authors. This is an open access article distributed under the terms of the Creative Commons Attribution License, which permits unrestricted use, distribution, and reproduction in any medium, provided the original author and source are credited. 
References

- $\quad$ Andersson, L.M., \& Pearson, C.M. (1999). Tit for Tat? The Spiraling effect of incivility in the workplace. Academy of management review, 24, 452-471.

- Chen, H., Ford,David L.,,Jr, Kalyanaram, G., \& Bhagat, R. S. (2012). Boundary conditions for turnover intentions: Exploratory evidence from china, jordan, turkey, and the united states. The International Journal of Human Resource Management, 23(4), 846. Retrieved from http://search.proquest.com/docview/923605090?accountid=44597

- Cho, M., Bonn, M.A., Han, S.J. and Lee, K. (2016). Workplace incivility and its effect upon restaurant frontline service employees and service performance. International Journal of contemporary Hospitality Management, 28 (12), 2888-2912.

- Cotton, J. and Tuttle, J. (1986). Employee turnover: A meta-analysis and review with implication for research. Academy of Management Review. 11(1), 55-70.

- Dormann, C. and Zapf, D. (2004), "Customer-related social stressors and burnout”, Journal of Occupational Health Psychology, Vol. 9 No. 1, pp. 61-82.

- Grandey, A.A., Kern, J.H. and Frone, M.R. (2007). Verbal abuse from outsiders versus insiders: Comparing Frequency, Impact on Emotional Exhaustion, and the Role of Emotional Labor. Journal of Occupational Health Psychology. 12(1), 63-79.

- Gulfnews.com (2008). UAE firms grapple with high staff turnover cost. Gulf news. Available at: http://gulfnews.com/business/sectors/general/uae-firms-grapple-with-high-staff-turnover-cost-1.149010

- Harhara, A. S. Singh, S. K. \& Hussain, M. (2015). Correlates of employee turnover intentions in oil and gas industry in the UAE. International journal of organizational analysis. 23(3), 493-504.

- Hur, W.M., Moon,T. and Jun, J.K. (2016). The effect of workplace incivility on service employee creativity: the mediating role of emotional exhaustion and intrinsic motivation. Journal of service marketing. 30(3), 302-315

- Kern, H., \& Stoner, M. (2009). Customer incivility as a social stressor: the role of race and racial identity for service employees. Journal of Occupational health Psychology. 14(1), 46-57.

- Li, X. \& Zhou, E. (2013). Influences of customer verbal aggression on employee turnover intention. Management decision, 51(4), 890-912.

- Maceda, C. (2014). Employee turnover remains a problem. Gulf news. http://gulfnews.com/business/sectors/careers/employee-turnover-remains-a-problem-1.1317901 (Accessed: 12 April 2017).

- Maceda, C. (2017). Staff retention is biggest challenge for companies in UAE: Study. Gulf news. Retrieved at 12 April 2017: http://gulfnews.com/business/sectors/employment/staff-retention-isbiggest-challenge-for-companies-in-uae-study-1.2078799

- McCarrick, E. (2008). Staff turnover costing UAE \$2.7bn a year. Gulf news. http://www.timeoutdubai.com/knowledge/news/4486-staff-turnover-costing-uae-27bn-a-year (Accessed: 12 April 2017).

- Medina, E. (2012). Job satisfaction and employee turnover intention: What does organizational culture have to do with it?. Columbia university academic commons, https://doi.org/10.7916/D8DV1S08.

- O’Halloran, P. (2012). Performance pay and employee turnover. Journal of economic studies, 39(6), 653-674.

- Peachey, J., Burton, L. \& Wells, J. (2014). Examining the influence of transformational leadership, organizational commitment, job embeddedness, and job search behaviors on turnover intentions in intercollegiate athletics. Leadership \& organization development journal, 35(8), 740-755.

- $\quad$ Poddar, A., \& Madupalli, R. (2012). Problematic customers and turnover inetntions of customer service employees. Journal of service marketing, 26(7), 551-559.

- Poon, J. (2004). Effects of performance appraisal politics on job satisfaction and turnover intention. Personnel review, 33(3), 322-334.

- $\quad$ Porath, C. \& Pearson, C. (2010). The cost of bad behavior. Organizational dynamics, 39(1), 64-71.

- Rahman, W. \& Nas, Z. (2013). Employee development and turnover intention: theory validation. European journal of training and development, 37(6), 564-579. 
Saeed, I., Waseem, M., Sikander, S., \& Rizwan, M. (2014). The relationship of turnover intention with job satisfaction, job performance, leader member exchange, emotional intelligence and organizational commitment. International Journal of Learning and Development, 4, 242-256.

- Samad, S. (2006). The contribution of demographic variables: Job characteristics and job satisfaction on turnover intentions. The journal of human resources and adult learning,

- Sharma, N. and Singh, V.K. (2016). Effect of workplace incivility on job satisfaction and turnover intention in India. South Asian Journal of Global Business Research, 5 (2), 234-249.

- Shabir, M., Abrar,M., Baig, S.A., \& Javed, M. (2014). The contribution of workplace incivility and psychological capital towards job stress. International journal of human resource studies. 4(2),

- Tepper, B.J. (2000). Consequences of Abusive Supervision. Academy of Management Journal. 43, 178-190.

- Tett, R.P., \& Meyer, J.P. (1993). Job satisfaction, organizational commitment, turnover intention, and turnover: Path analysis based on meta analytic findings. Personnel psychology, 46(2), 259-293.

- Pearson, C.M., Andersson, L.M. and Wegner, J.W. (2001). When workers flout convention: a study of workplace incivility. Human relations, 54 (11), 1387-1419.

- Zimmerman, R., \& Darnold, T. (2009). The impact of job performance on employee turnover intentions and the voluntary turnover process, Personnel review, 38(2), 142-158.

Resources

The research will be self-funded, access to copyright material, access to SMEs, etc. 